\title{
ANCIENT BACTERIAN BRONZE AGE FIRE WORSHIP
}

\author{
Komil Akramovich Rakhimov
}

National Center of Archeology Academy Of Sciences Of The Republic Of Uzbekistan

\section{ABSTRACT}

This article gives a brief overview of the results of research on the monuments of the Sopolli culture in northern Bactria, as well as the origin, shape, size, functions, stages of development, geography of distribution, geography of other cultures. comparisons with the findings of the eneolithic and Bronze Ages and comments on their periodic dates. It has also been scientifically substantiated that double-fire fireworshiping furnaces in the eneolithic period continued as a tradition in later periods, i.e. in the Bronze Age, and that these furnaces were observed not in centralized temples but in family houses.

KEYWORDS: - Ancient Bactria, Eneolithic, Chopontepa, Geoksyur, Altyndepe, Sapalli, Jarqo'ton, Dashly, Gonur-depe, Yassitepa, Chakmakli, Pessedjik, Togolok, Keleli, altar, fire, hearth, temple

\section{INTRODUCTION}

Furnaces found in the Stone Age sites were not only for food processing, but also for the creation of comfortable living conditions, but also as a socio-cultural center that reflected the economic, industrial and ideological unity [1, p. 161]. The worship of eternal fire was apparently widespread among the peoples of Indo-Europe, who saw some kind of divine power in the burning flame.

It is known that the peoples of Central Asia from ancient times began to believe in the sun, that is, fire as a part of it. The worship of fire, its temples, and Zoroastrianism originated on the basis of a fire-worshiping religion.

The main religious deity of Zoroastrianism is the sun and its fragment is fire, which is the main purifying element in Zoroastrianism, and its traces have played an important role in religious sites, burial rites, lifestyles and religious ceremonies of ancient ancestors[2, p. 1995-
1999]. At the same time, Zoroastrians base their beliefs on the struggle between two gods. Ahuramazda is a symbol of goodness, Ahriman is a symbol of evil. The fire, which is a symbol of salvation, is supposedly created by Ahuramazda, and the fire serves as a reliable tool in the fight against the giant Ahriman.

The peoples living in these areas have not practiced their religious rites without fire since time immemorial. This process began in the Eneolithic period, when the custom of divine worship around special devices. This ritual is reflected in the material sources studied in the monuments of the Eneolithic period Sarazm, Geoxyur, Changtepa and Aynatepa. During this period it was discovered that there was one common place of worship for the whole community. Similar rooms have been discovered in the Naked, Yassitepa, Chakmakli, Pessedjik, Geoxyur and other monuments of southern Turkmenistan [3, p. 44-45; 4, p. 87-89; 5, - p. 1213]. 
CURRENT RESEARCH JOURNAL OF HISTORY 2(5): 71-77, May 2021

DOI: https://doi.org/10.37547/history-crjh-02-05-17

ISSN 2767-472X

(C)2021 Master Journals

\section{Crossref dof 81 Google}

Accepted 25th May, 2021 \& Published 31 th May, 2021

Archaeological excavations of Bronze Age monuments have shown that the fires were of two types, namely circular and square [6, p. 7078]. The circle has been accepted by many researchers as a symbol of the sun $[6, \mathrm{p} .74 ; 7, \mathrm{p}$. 47-51]. The rectangle, on the other hand, represented the four elements of the world, "fire - water - earth - air", and thus a solid system, a whole was achieved, uniting the basic lines of the universe [8, p. 630]. Therefore, fires of this type are considered sacred. The discovery of a circular altar in a woman's tomb Although Mother Earth is revered close to the sun, which shares energy and heat, we can interpret the man as the guardian of the four sacred elements, namely, the sanctity and purity of the earth, fresh air and water. The walls of the fireplaces are made of specially baked clay, they are made of clean earth, there are no additives in the composition. They are mainly made on sofas built at a height of 50-60 cm in the central part of the rooms.

Circle-shaped fires have been known in Central Asia since the Eneolithic period. While the oldest flares have been studied in the Sarazm, Aynatepa, Changtepa, Geoksur monuments, by the Bronze Age the geography of the spread of the flares expands. In the Caucasus, the occurrence of Kura in the monuments of the Araks culture, in the monuments of the Harappa culture, indicates that fire has begun to occupy a central place in the religious imaginations of the peoples of the East and the Caucasus. The largest in Togolok - $3 \mathrm{~m}$. the encounter of a diameter fire shows that the whole community worshiped the fire. According to archeological data, circular fires in the Central Asian region have been observed since the Eneolithic period, but spread to large areas by the Bronze Age.

Circular fires have been found in Eneolithic monuments in southern Turkmenistan, Suza in Iran, Sarazm in Zarafshan, and other monuments. N.A. Avanesova's research According to, a large number of miniature, dwarf fires were found in Boston VI Cemetery. They are in the shape of a circle, completely replicating the shape of real fires.

Rectangular fires are observed in the Bronze Age strata of Sarazm, in monuments such as Oltintepa, Ilk Tulkhar, Dashli, and in terms of distribution do not occupy a much larger area than circular fires and are numerically deficient. In the case of Jarqo'ton, it is difficult to believe that the square-shaped fires were divine in nature. Because it is located in the center of a simple utility room, the walls are burnt like a furnace and seem to have served as a furnace rather than a natural divinity. In general, circular fireplaces are characteristic of Sopolli culture, and its earliest specimens, i.e. prototypes, are also found in tombs.

The coals burned in the fires were kept in special pots, and the inhabitants of the Bronze Age considered the fire sacred and regarded the ashes as its product. For this reason, the inhabitants of the Sopolli culture not only trampled the ashes of the burning fire, but also revered it as sacred as fire.

\section{THE MAIN FINDINGS AND RESULTS}

10 fire places of worship of different stages of pottery culture were identified, 8 of them were identified in the Jarqo'ton fire temple, and 2 in the "ark" [9, p.15 p; 10, p. 66-78]. According to the researchers, although there were special, i.e. family worship centers in the eneolithic and Early Bronze Ages, it was also noted that there were family and collective fire-worship practices based on Jarqo'ton materials [11, p. 59-68; 12, p. 6-8; 6, p. 77].

The fires found at the Jarqo'ton monument were discovered by T.Sh. Shirinov's according to plan, he divided them into circles and squares and gave detailed information about their function, geography and chronology of distribution $[6, p$. 
70-78].

In general, the main focus of many years of archeological research on the monuments of Sopolli culture is to observe the formation and development stages of the local Bactrian hearth of ancient Eastern civilization in the upper basins of the Amu Darya, to study the problem of early urban culture and the emergence of the first state system.

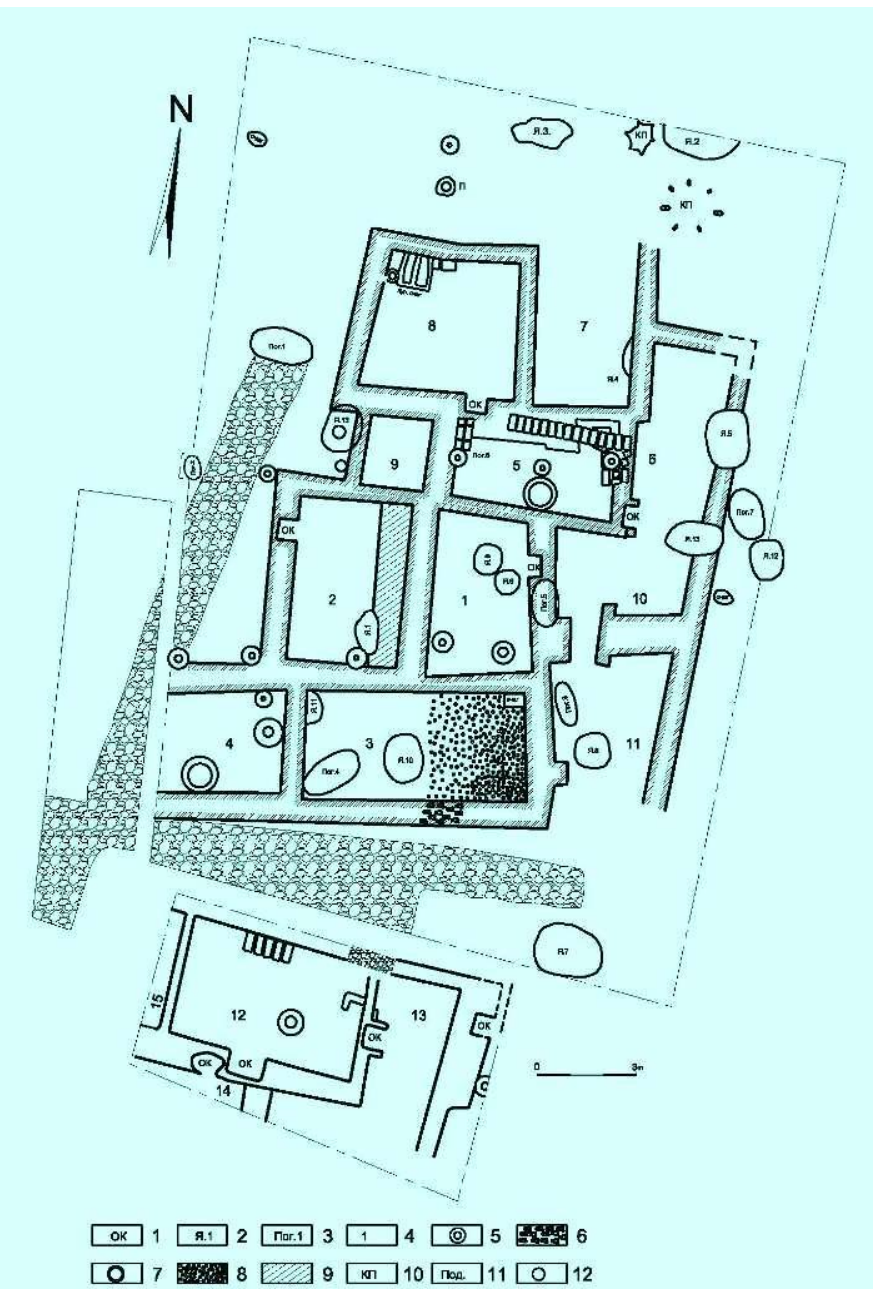

Fig. 1

As a result of scientific research conducted in recent years at the Jarqo'ton monument, the location of a house inhabited by a large patriarchal family consisting of many rooms has been explored here (Fig. 1). The courtyard, stone walkways, and adjoining living rooms of this large patriarchal family house were explored. An analysis of the materials obtained here showed that the house belonged to two construction periods. The courtyard and hallways functioned in both periods. The places of worship - the fires - were in the form of a circle, in which the 
presence of layers of ash was observed. The fireplaces are built on a special platform 40-50 $\mathrm{cm}$ above the floor of the room. In the courtyard on the north side of the house, it was found that there were two adjacent two-tiered pottery jars belonging to the Jarqo'ton stage [13, p. 42-47]. However, archeological research conducted here has yielded new material on fire-worshiping hearths. Therefore,

Fig. 1.in this article we would like to make some comments based on new information about the shape, size, function, geography of distribution of the doublefired fire-worshiping furnace, which was discovered for the first time at the Jarqo'ton monument.

In the 8th room of a multi-room house belonging to the large patriarchal family mentioned above, a double-fire fire-worshiping furnace was opened and studied

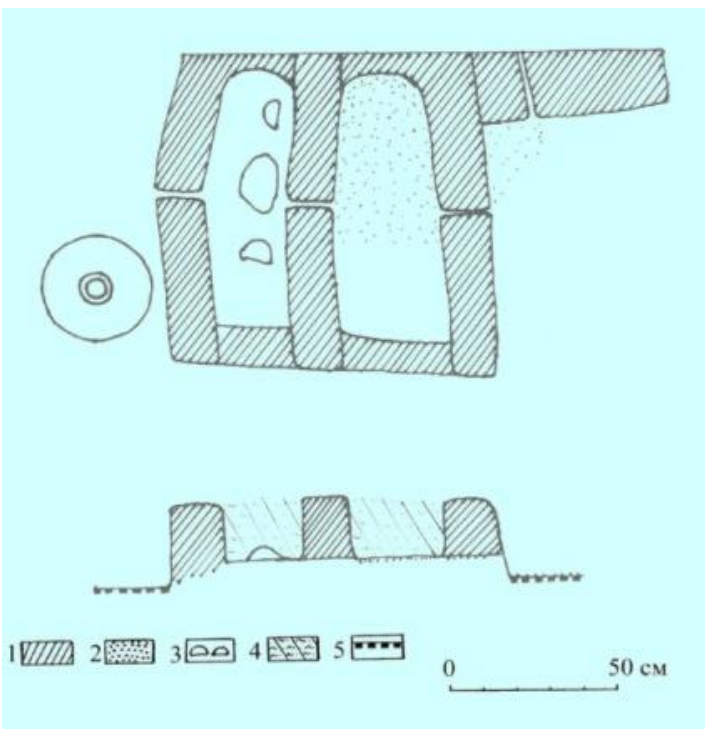

(Fig. 2).

The room is rectangular in shape and measures $4.85 \times 4.10 \mathrm{~m}$. The oven is built into the north wall of the room. The overall view of the furnace is square and measures $1.02 \times 1 \mathrm{~m}$. The furnaces of the furnace are rectangular in shape, the size of one of the furnaces is $83 \times 24 \mathrm{~cm}$ and the other is $86 \times 33 \mathrm{~cm}$. The walls of the kiln are made of raw brick, its thickness is $14 \times 16 \mathrm{~cm}$, height is $20-22$ $\mathrm{cm}$. The hearths of the kilns were plastered very thinly with straw-mixed clay, and the walls did not burn too much under the influence of fire. The floor of the kiln is the same, the floor is covered with a layer of soft soil. Under the floor of the western kiln there are three pieces of raw stone and on the floor of the eastern kiln there are small stones, the upper part of which is plastered with straw.

Fig. 2

Based on the above analysis, it should be noted that the furnace did not have a strong fire and the walls did not exceed $20-22 \mathrm{~cm}$ in height like the walls of the furnace, the boiler was not built to fit the pot and the interior of the furnace was not too red. That is, they may have been used in ceremonies associated with the sacred fire, not in cooking. In addition, the walls of the furnace did not burn very strongly under the influence of fire, as evidenced by the cleanliness of the interior of the furnaces, which was always cleaned of ash from the inside after the ceremony, and at the same time, the fire was brought to the furnace during the ceremony.

According to our stratigraphic observations, the fact that the double-fired furnace was built at the same time as the house and the installation of a pottery of the Jarqo'ton stage of the Sopolli culture on its western side serves as the main source in determining its periodic date. This type of fire-worshiping hearth is being discovered for the first time in the monuments of Sopolli culture.

\section{Results AND DISCUSSION}

V.I. Sarianidi double-hearth furnaces were discovered and studied by in the Yalangochtepa 
CURRENT RESEARCH JOURNAL OF HISTORY 2(5): 71-77, May 2021

DOI: https://doi.org/10.37547/history-crjh-02-05-17

ISSN 2767-472X

(C)2021 Master Journals

\section{Crossref dof 81 Google}

Accepted 25th May, 2021 \& Published 31 th May, 2021

and Oltintepa monuments of the Geoxyur oasis of the Eneolithic period [14, p. 42; 3, p. 24].

A double-fired kiln is also found at the Kelleli VI monument in the Murgab oasis, and it was built by I.S. Masimov found that it belongs to the beginning of the II millennium $\mathrm{BC}[15, \mathrm{p} .117]$.

In the Dashli-3 temple of the Bronze Age of ancient Bactria, it was found that there were two and even three fireplaces with a rectangular shape in front of the wall [7, p. 34-36; 16, p. 17].

V.I. Sarianidi although noted that the double fireplace in Yalangochtepa was designed for the worship of the sacred fire [3, p.24], subsequent research suggests that instead of this type of stove at the Gonurtepa monument and having all the amenities for cooking, food was prepared for sacrifice in this oven. past [17, p.98].

Although the researchers noted these furnaces as examples of material culture and did not analyze them comparatively with materials from other monuments, they commented on the function of these devices at that time.

Based on the above considerations, we also believe that the double fireplace in front of the wall found in the eighth room of the house in the southern part of the Jarqoton "ark" served to worship the fire. This is confirmed by a number of material evidences related to this finding. This is because there is no strong fire in this furnace, the side walls are not very high, and there is no need to heat two rooms in one room at a time.

The characteristic feature of these furnaces is that, although the furnace is full of ashes, there are no signs of strong fire on the walls. Material sources indicate that while the circular fireplaces at the Jarqoton monument were built in the courtyard of the temple, mostly in open courtyards, the double fireplace was built in the rooms of a house belonging to the patriarchal family.

In addition, from the above comparative analysis, it was found that these types of furnaces are found in the temples of the Gonurtepa, Dashli monuments, and in the fire-worshiping rooms of the Yalangochtepa, Oltintepa, and Keleli monuments.

It is known that the peoples of Central Asia from ancient times began to believe in the sun, that is, fire as a part of it. According to the analysis of archeological sources, the existence of sun worship in Central Asia from the Eneolithic period was noted in the example of fires [6, p. 6979]. The peoples living in these areas have not performed religious rites without fire since time immemorial.

During the Neolithic and Eneolithic periods, that is, during the time of the blood-brotherhoodbased seed community, the community's separate shrines began to appear. It is typical for the whole community to have one common worship room during this period. Similar rooms have been discovered in the monuments of Pessejik, Chakmakli, Yassitepa, Yalangach and Sarazm [18 ;; 2.p. 24; 4.p. 87-89]. With the emergence of patriarchal families, the existence of each patriarchal family's own worship rooms V.M. Masson Observed by on the example of the Oltintepa monument [19, p. 165]. In the Yalangachtepa monument, similar rooms are slightly larger than ordinary living rooms, with mud plastered on the walls and decorated with divine symbols. The divine furnaces located in these rooms are radically different from the household furnaces, and the fireplace is divided into two. Due to the low fire in the furnaces, the furnace walls did not burn strongly [4, p. 87-89]. The presence of patriarchal families in their own rooms of worship, the location of circular fireplaces in these rooms was preserved until the late Bronze Age [14, p. 35-55]. This is evidenced by the fact that a separate place of worship was recorded in the rooms belonging to patriarchal families at the Jarqo'ton monument. 
CURRENT RESEARCH JOURNAL OF HISTORY 2(5): 71-77, May 2021

DOI: https://doi.org/10.37547/history-crjh-02-05-17

ISSN 2767-472X

(C)2021 Master Journals

Crossref doi 81 Google

Accepted 25th May, 2021 \& Published 31 th May, 2021

With the emergence of the first city-states, temples began to be built for the whole community. Examples of such temples are the Bronze Age temples studied in the monuments of Jarqo'ton, Dashli, Gonur, Tugoloq. It is noted that in ancient Bactria, during the rise of government to the city-state level, central monumental temples appeared, and at the same time, family and community shrines of the population did not lose their place [20, p. 20-21]. Jarqo'ton temple was built by T.Sh. Shirinov although stated in his early research that it was built for the sun $[6, \mathrm{p}$. 69-78], and in his later scientific works he advanced the first Zoroastrian theory [7, p. 3142; 21, pp. 35-47]. Based on a scientific analysis of the glyptics and sphragistics of the pottery culture, the researcher noted that in the culture community the beliefs of fertility, water and fire and haoma were revered, but the main deity was the sun god and the Jarqo'ton temple was dedicated to the sun god [22, p.18].

\section{Conclusion}

It should also be noted that double-hearth furnaces are also found in monuments such as Geoxyur, Oltintepe, Keleli, Dashli Gonur. we can pass.

In conclusion, it should be noted that instead of locating the fireplaces and places of worship studied at the Jarqoton monument, a fire was worshiped as a group in the centralized temple, and the Copper-Stone Age tradition continued, ie in the Bronze Age, special fire was used in each patriarchal family. proves that there were rooms of worship. It is also possible to say that the double fireplaces are designed for the daily ceremonies of family members, while the circular and square fireplaces are of a collective nature and are designed for large ceremonies.

\section{REFERENCES}

1. Masson V.M. Ogon $\mathrm{V}$ epoch paleolita: mnogoobrazie funktsiy // SA, № 1. M.: 1991.

2. On the Appearance of the Ritual of Burning the Corpse at the Funeral of the Last Bronze Age of the Northern Bactria // Journal of Advanced Research in Dynamical and Control Systems. 16 Nov 2020. Jour of Adv Research in Dynamical \& Control Systems, Vol. 12, 07-Special Issue, 2020.

3. Sarianidi V.I. Kultovye zdaniya poseleniy anauskoy kultury.// SA. M.: 1962, №1.

4. Xlopin I.N. Model round victim from Yalangach-depe // KSIA, №98. M., 1964.

5. Sarianidi V.I. Pamyatniki pozdnego eneolita yugo-vostochnoy Turkmenii // Archeologiya SSSA. SAI. B. 3-8. Chast 4. M., 1965.

6. Shirinov T.Sh. Altari ognya iz xrama Djarkutana - a monument of the epoch of bronze development of southern Uzbekistan // IMKU. - Tashkent, 1990.

7. Sarianidi V.I. Ancient lands of Afghanistan. M., 1977.

8. Mify the peoples of the world. V dvux tomax, t. 1. M., 1980.

9. Askarov A.A., Shirinov T.Sh. Drevnebaktriyskiy shram ognya $\mathrm{v}$ Yuzhnom Uzbekistane // Gradostroitelstvo i arhitektura. Tashkent, 1989.

10. Askarov A.A., Shirinov T.Sh. Rannyaya gorodskaya kultura epoxi bronzy yuga Sredney Azii. Samarkand, 1993.

11. Rahimov K.A. Reflections on the Bronze Age fires of Bactria // History of material culture of Uzbekistan. No. 39. Samarkand, 


\section{5.}

12. Rahimov K.A. Some comments on the study of ceramics. // Proceedings of the Republican scientific conference "Development of archeology in Karakalpakstan during the years of independence." Nukus-2015.

13. 13 Raximov K.A. Keramicheskie pechi sapallinskoy kulturы (po rezultatam rabot sovmestnoy Uzbeksko-Germanskoy archeologicheskoy ekspeditsii) // Vestnik.Mejd. Institute of Central Asian Studies.№ 2. Samarkand- Bishkek, 2005.

14. Masson V.M. Altyn-depe // Trudy YuTAKE.T. XVIII. L., 1981.

15. Masimov I.S. New research of monuments of Bronze Age epochs in Murgab // Ancient civilizations of the East (Materials of the II Soviet-American Symposium). Tashkent, 1986.

16. Sarianidi V.I. Izuchenie pamyatnikov epoxi bronzy i rannego jeleza $v$ Severnom Afganistane // KSIA, №132. M., 1972.

17. Sarianidi V.I. Gonur depe (Gorod tsarey i bogov) Ashgabat "Meros", 2006.

18. Berdiev 0 . Material culture of Turkmenistan in the Neolithic period and early Eneolithic // Pervobytnyy Turkmenistan. Ashgabat, 1976.

19. Mason V.M. Altyndepe in the Eneolithic epoch. SA. №3. 1977.

20. Karimova D.O. Funerals and religious beliefs of the people of Northern Bactria (on the example of material monuments of the Bronze Age). // Disser. avtoref. Doctor of Philosophy in History (PhD) Tashkent, 2017.

21. Shirinov T.Sh. Srednyaya Aziya vo II tysyachaletii do nashey ery i protozoroastrizm

Samarkand, 2000

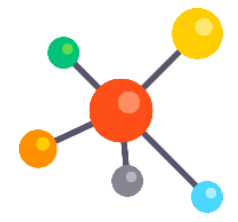

22. Shaydullaev A.Sh. Glyptics and sphragistics of pottery culture. // Disser. avtoref. Doctor of Philosophy in History (PhD) Tashkent, 2018.

23. Rasuljanovna, I. N., \& Rakhmonqulovich, K. N. (2020). Trade Relations Between Ancient Bacteria And China On The II-I BC. The American Journal of Social Science and Education Innovations, 2(07), 47-51. 